\title{
VOCALIZATION OF BROILERS CAN BE USED TO IDENTIFY THEIR SEX AND GENETIC STR AIN
}

Doi:http://dx.doi.org/10.1590/1809-4430-Eng.Agric.v35n2p 192-196/2015

\section{ERICA M. PEREIRA ${ }^{1}$, IRENILZA DE A. NÄÄS ${ }^{2}$, RODRIGO G. GARCIA ${ }^{3}$}

\begin{abstract}
In order to reach higher broiler performance, farmers target losses reduction. One way to make this possible is by rearing sexed broilers as male and female present diverse performance due to their physiological differences. Birds from different genetic strain also have a distinct performance at the same age. Considering that sexed flocks may present higher performance this study aimed to identify one-day-old chicks' sex throughout their vocalization. This research also investigated the possibility of identifying the genetic strain by their vocalization attributes. A total of 120 chicks, half of them were from $\mathrm{Cobb}^{\circledR}$ genetic strain and the other half from Ross ${ }^{\circledR}$ genetic strain. From each group, a total of 30 were males and 30 females, which were previously separated by sex using their secondary physiological characteristics at the hatchery. Vocalizations audio recording was done inside a semi-anechoic chamber using a unidirectional microphone connected to an audio input of a digital recorder. Vocalizations were recorded for two minutes. Acoustic characteristics of the sounds were analyzed being calculated the fundamental frequency Pitch, the sound intensity, the first formant, and second formant. Results indicated that the vocalizations of both sexes could be identified by the second formant, and the genetic strain was detected by both the second formant and the Pitch.
\end{abstract}

KEYWORDS: signal analysis, sex identification, bioacoustics.

\section{VOCALIZAÇÃO DE FRANGOS DE CORTE PODE SER USADA PARA IDENTIFICAR O SEXO E A LINHAGEM GENÉTICA}

RESUMO: Com a finalidade de atingir maior desempenho em frangos de corte, produtores almejam redução de perdas. Uma das maneiras de se tornar isto possível é alojar lotes sexados, uma vez que machos e fêmeas apresentam desempenho distinto devido às diferenças fisiológicas. Aves de linhagens genéticas diferentes também apresentam desempenho distinto na mesma idade. Considerando que lotes sexados podem apresentar maior desempenho, este estudo objetivou identificar o sexo de pintos de um dia de idade através de sua vocalização. Esta pesquisa também investigou a possibilidade de identificar a linhagem genética através dos atributos da vocalização. $\mathrm{O}$ total de 120 pintos, sendo metade da genética $\mathrm{Cobb}^{\circledR}$ e a outra metade da genética Ross ${ }^{\circledR}$, foram utilizados. De cada grupo, o total de 30 machos e 30 fêmeas foi previamente separado, utilizando suas características fisiológicas secundárias, no incubatório. O registro áudio de vocalização foi efetuado dentro de uma câmara semi anecoica, usando um microfone unidirecional conectado a uma entrada de áudio em um gravador digital. As vocalizações foram gravadas por dois minutos. As características acústicas dos sons foram analisadas e foram calculadas a frequência fundamental Pitch, a intensidade do som, a primeira formante e a segunda formante. Os resultados indicaram que a vocalização de ambos os sexos pode ser identificada pela segunda formante, e a linhagem genética pela segunda formante e pela frequência de Pitch.

PALAVRAS-CHAVE: análise de sinais, identificação de sexo, bioacústica.

\footnotetext{
${ }^{1}$ Eng $^{\circ}$ de Telecomunicações, doutora, Faculdade de Engenharia Agrícola, Unicamp/Campinas - SP, Fone: (19) 98115-4996, ericamourapereira@gmail.com.

${ }^{2}$ Eng. Civil, Profa. Colaboradora, Faculd ade de Engenharia A grícola, Unicamp/Campinas - SP, irenilza@ gmail.com

${ }^{3}$ Zootecnista, Prof. Doutor, Faculdade de Ciências Agrárias, Universidade Federal da Grande Dourados/Dourados - MS, rodrigogarcia@ufgd.edu.br 


\section{INTRODUCTION}

Broiler (Gallus gallus domesticus) production nowadays is within a small profit margin and the farmers' aims best performance by reducing production costs. For achieving the flocks need to be sexed, as males and females reach final weight at different age, and birds' performance is also related to the genetic strain.

Animal vocalization analysis is becoming an important non-invasive welfare indicator. It might identify unusual traits related to animals' status (MANTEUFFEL \& SCHÖN, 2004; CORDEIRO et al., 2009; GRANDIN, 2010; CHAN et al., 2011). Other studies show vocal signals as a prominent tool to identify the animals' sex (FISCHER et al, 2004; VOLODIN et al., 2005; VANNONI \& MCELLIGOTT, 2008). Broiler sexing is a time-consuming task. It might be done using DNA methods or the visual observation of physical characteristics, such as the cloaca or feathering appearance (VOLODIN et al., 2005; CERIT \& AVANUS, 2007; VOLODIN et al., 2009). Current literature presents a positive correlation between frequency of vocalization and dominance of males, indicating the possibility of identifying the males by the vocalization features (VANNONI \& MCELLIGOTT, 2008; FISCHER et al., 2004). VOLODIN et al. (2009) compared the ducks vocal sex recognition with other two invasive methods (DNA and cloaca inspection), and found that the fundamental formant may be used for separating the birds by sex with the same precision as the molecular analysis.

This study aimed to identify broiler sex and genetic strain using the attributes of their vocalization.

\section{MATERIAL AND METHODS}

\section{Birds and husbandry}

A total of 120 one-day-old chicks, 60 of them were from $\mathrm{Cobb}^{\circledR}$ genetic strain and 60 from Ross $^{\circledR}$ genetic strain. From each group, a total of 30 were males and 30 females, which were sexed previously using their secondary physiological characteristics at the hatchery. After arrival, the birds were kept in an experimental house with $5 \mathrm{~cm}$ of the new litter with an ambient temperature of $33{ }^{\circ} \mathrm{C}$. Feed ration and water were available ad libitum.

This experiment had the approval of the ethics committee of the College of Agrarian Sciences, from the Federal University of Grande Dourados, MS, Brazil, protocol number 03/2011.

\section{Data recording and vocalization analysis}

Vocalization recording was done inside a semi-anechoic chamber with dimensions of $90 \mathrm{~cm}$ long and $50 \mathrm{~cm}$ wide and $40 \mathrm{~cm}$ high. The temperature inside the chamber was made with the threshold of $17-18{ }^{\circ} \mathrm{C}$ in order to expose the birds to cold stress and induce them to vocalize. Sounds were recorded for 2 min using a unidirectional microphone (Yoga ${ }^{\circledR}$ Electronics Co., Taipei, Taiwan) positioned about $15 \mathrm{~cm}$ from the birds' beak. The microphone was connected to a digital recorder (Marant ${ }^{\circledR}$ PMD 660), where the signals were digitized at a $44,100 \mathrm{~Hz}$ frequency. The recorded sounds were edited and analyzed by using the Praat ${ }^{\circledR}$ software (CORDEIRO et al., 2013). From each recorded audio signal $45 \mathrm{~s}$ were randomly selected to be analyzed using the Praat ${ }^{\circledR}$ software. Four acoustic parameters were calculated for differentiate the sex of the chicks: 1 vocalization intensity; 2 - fundamental frequency (pitch); 3 -first formant (F1); and 4 - second formant (F2)

Sound intensity is a property of the audio that measures the energy flow per unit of area (dB). Fundamental frequency (Pitch; Hz) is considered one of the main characteristics of the sound, and it is the frequency perceived by the human ear. Formants (kcal) are defined as peak of the energy of the spectral sound that is found in a determined sound source.

The research was distributed in a factorial analysis $(2 \times 2)$ with two sex and two genetic strains. Results were tested with respect to normality and afterward the calculated means were tested using 
t-Student test and Fishers' test at 5\% significance levels, and the Statistical Analysis System (SAS, 2001) statistical package.

\section{RESULTS AND DISCUSSION}

Using the t- Student test it was possible to differentiate sex in a group of $\mathrm{Cobb}^{\circledR}$ chicks using $\mathrm{F} 1$ ( $\mathrm{p}=0.001)$. Or, using the Fisher test, the parameter that differ the chicks sex was $\mathrm{F} 2(\mathrm{p}<0.0001)$. For identifying the sex of Ross ${ }^{\circledR}$ chicks using the t-Student test the parameter F2 $(\mathrm{p}=0.001)$ is appropriate to be used. Or yet the pitch frequency $(\mathrm{p}<0.0004)$, when using the Fisher test (Table 1).

TABLE 1. Statistical results for differing the chick's sex within the genetic strains, $\mathrm{Cobb}^{\circledR}$ and Ross ${ }^{\circledR}$.

\begin{tabular}{cccc}
\hline \hline \multirow{2}{*}{ Genetic strain } & \multirow{2}{*}{ Sound parameter } & \multicolumn{2}{c}{ P-value } \\
\cline { 3 - 4 } & $\mathrm{F} 1$ & t-Student test & Fishe rs' test \\
\hline \multirow{2}{*}{ Cobb $^{\circledR}$} & $\mathrm{F} 2$ & 0.001 & $\mathrm{NS}$ \\
& Pitch & $\mathrm{NS}$ & $7.3843 \mathrm{E}^{-14}$ \\
& Intensity & $\mathrm{NS}$ & $\mathrm{NS}$ \\
\multirow{2}{*}{ Ross $^{\circledR}$} & $\mathrm{F} 1$ & $\mathrm{NS}$ & 0.0009 \\
& $\mathrm{~F} 2$ & $\mathrm{NS}$ & $\mathrm{NS}$ \\
& Pitch & 0.001 & $\mathrm{NS}$ \\
& Intensity & $\mathrm{NS}$ & 0.0004 \\
\hline
\end{tabular}

NS=non-significant by t-Student test or Fishers' test.

Different from mammals, whose sexual recognition is mostly by olfactory stimuli, birds detect sex and identity of conspecifics regularly by visual and acoustical performances. In most species, male calls are lower in frequency than female calls (VOLODIN et al., 2005). For this reason, using the parameter F1 or F2 could be useful in differ the sex, as it was found in the present study. Male cockerel (Gallus gallus) calls have been previously studied when they are related to a group of risk facing a predator. In this case, the male emits a large band pulse call at the beginning of an alarm call, with a sequence of critical calls (BAYLY \& EVANS, 2003). These calls are different from the female of the same species, similar to the results found in the present study. VOLODIN et al. (2009) studying wild ducks discovered that males also exhibit different vocalization from the females of the same species during mate.

The difference found in male and female vocal repertoire could be attributed to the difference in their morphological characteristics (GEBERZAHN et al, 2009). However, commercial broiler chicks are monomorphic birds; for this reason, the role of the anatomical formation is minimized, especially at a very young age.

When grouping the genetic strains and separating the parameters by sex (female and male), the results indicate that the sex can be differed using the Fishers' test with the F2 parameter ( $\mathrm{p}<$ 0.05 ), as seen in Table 2.

The domestic fowl is an ideal species to study the risk-taking behavior in the context of signaling species, since the production of aerial alarm calls is influenced by the effect of the group composition (KOKOLAKIS et al., 2010). Individual variation in alarm calls and another vocal repertoire during mating identifies dominance and determines reproductive success in the wild bird species (WILSON \& EVANS, 2008; BRUMM et al., 2009; BAKER et al., 2012; PILLAY \& RYMER, 2012). In the present study, males presented different repertoire than females. This result is probably associated with the wild reminiscent and evolutionary reproductive function (WILSON \& EVANS, 2008; GEBERZAHN et al., 2009; RANDALL et al., 2009). Similar results were reported in the literature with respect to identifying birds' sex by the analys is of their vocalization acoustic parameters (VOLODIN et al., 2009), as well as the study of vocalization of other animal species (VANNONI \& MCELLIGOTT, 2008) including primates (FISCHER et al. 2004). 
TABLE 2. Statistical results for differentiating the female and male chicks grouping both genetic strains.

\begin{tabular}{cccc}
\hline \hline \multirow{2}{*}{ Sex } & \multirow{2}{*}{ Parameter } & \multicolumn{2}{c}{ P-value } \\
\cline { 2 - 4 } & & t-Student test & Fishe rs' test \\
\hline \multirow{3}{*}{ Female } & F1 & NS & NS \\
& F2 & NS & 0.0046 \\
& Pitch & NS & NS \\
& Intensity & NS & NS \\
\hline \multirow{2}{*}{ Male } & F1 & NS & NS \\
& F2 & NS & NS \\
& Pitch & NS & NS \\
\hline
\end{tabular}

NS=non-significant by t-Student test or Fishers' test.

Determining the threshold of male and female vocalization with accuracy requires the help of information technology tools. It is possible to implement a system that may electronically select commercial chicks' sex and genetic strain using specific algorithms.

\section{CONCLUSIONS}

It was possible to distinguish all birds' sex using the formant F2. To differentiate the chicks by the genetic strain either the formant F2 or the formant pitch may be used, as both sound attributes were statistically different.

It is important to mention that this evidence is not usually detected by a non-trained human ear.

\section{ACKNOWLEDGEMENT}

The authors wish to thank FAPESP for the doctoral scholarship.

\section{REFERENCES}

BAKER, T. M.; WILSON, D. R.; MENNILL, D. J. Vocal signals predict attack during aggressive interactions in black-capped chickadees. Animal Behaviour, Amsterdam, v. 84, n 4, p. 965-974, 2012.

BAYLY, K. L.; EVANS, C. S. Dynamic changes in alarm call structure: a strategy for reducing conspicuousness to avian predators? Animal Behaviour, Amsterdam, v.140, n. 3, p. 353-369, 2003.

BRUMM, H.; SCHMIDT, R.; SCHRADER, L. Noise-dependent vocal plasticity in domestic fowl. Animal Behaviour, Amsterdam, v.78, n.3, p.741-746, 2009.

CERIT, H.; AVANUS, R. Sex identification in avian species using DNA typing methods. World's Poultry Science Journal, Cambridge, v. 63, n. 1, p. 91-99, 2007.

CHAN, W. Y.; CLOUTIER, S.; NEWBERRY, R. C. Barking pigs: differences in acoustic morphology predict juvenile responses to alarm calls. Animal Behaviour, Amsterdam, v. 82, n. 4, p.767-774, 2011.

CORDEIRO, A. F. S.; PEREIRA, E. M.; NÄÄS. I. A.; SILVA, W. T., MOURA, D. J. Medida de vocalização de suínos (Sus scrofa) como um indicador de gasto energético. Revista Brasileira de Engenharia de Biosistemas, Campinas, v.2, p.143-152, 2009.

CORDEIRO, A. F. S.; NÄÄS. I. A.; OLIVEIRA, S.R.M.; VIOLARO, F; ALMEIDA, A.C.M.; NEVES, D.P. Understanding vocalization might help to assess stressful conditions in piglets. Animals, Basel, v.3, n. 3, p. 923-934, 2013. 
FISCHER, J., KITCHEN, D. M., SEYFARTH, R. M.; CHENEY, D. L. Baboon loud calls advertise male quality: acoustic features and their relation to rank, age, and exhaustion. Behavioral Ecology and Sociobiology, Berlin, v. 56, n. 2, p. 140-148, 2004.

GEBERZAHN, N.; GOYMANN, W.; MUCK, C.; TEN CATE, C. Females alter their song when challenged in a sex-role reversed bird species. Behavioral Ecology and Sociobiology, Berlin, v. 64, n. 2, p 193-204, 2009.

GRANDIN, T. Auditing animal welfare at slaughter plants. Meat Science, Amsterdam, v. 86, n. 1, p. 56-65, 2010.

KOKOLAKIS, A.; SMITH, C.L.; EVANS, C. S. Aerial alarm calling by male fowl (Gallus gallus) reveals subtle new mechanisms of risk management. Animal Behaviour, Amsterdam, v.79, n.6, p. 1373-1380, 2010.

MANTEUFFEL, G.; SCHÖN, P. C. Measuring pig welfare by automatic monitoring of stress calls. Bornier Agratechnische, Bericht, v.29, n. 1, p.110-18, 2004.

PILLAY, N.; RYMER, T. L. Behavioural divergence, interfertility and speciation: A review. Behavioural Processes, Amsterdam, v. 91, n. 3, p. 223-235, 2012.

RANDALL, D.; OWREN, M. J.; MICHAEL J.; RYAN, M. J. What do animal signals mean? Behaviour, Leiden, v.78, n.2, p.233-240, 2009.

SAS - Statistical Analysis System. System for Microsoft Windows. Cary, 2001.

VANNONI, E.; MCELLIGOTT, A. G. Low frequency groans indicate larger and more dominant fallow deer (Dama dama) males. PLoS ONE, Washington, v.3, n.9, e 3113, 2008.

VOLODIN, I. A.; VOLODINA, E. V.; KLENOVA, A. V.; FILATOVA, O. A. Individual and sexual differences in the calls of the monomorphic white-faced whistling duck Dendrocygna viduata. Acta Ornithologica, Warsaw, v.40, n. 1, p.43-52, 2005.

VOLODIN, I.; KAISER, M.; MATROSOVA, V.; VOLODINA, E.; KLENOVA, A.; FILATOVA, O.; KHOLODOVA, M. The technique of noninvasive distant sexing for four monomorphic dendrocygna whistling duck species by their loud whistles. Bioacoustics: The International Journal of Animal Sound and its Recording, Abingdon, v.18, n. 3, p. 277-290, 2009.

WILSON, D. R.; EVANS, C. S. Mating success increases alarm-calling effort in male fowl, Gallus gallus. Animal Behaviour, Amsterdam, v.76, n. 6, p.2029-2035, 2008. 